Int. J. Electrochem. Sci., 15 (2020) $2727-2738$

\title{
Ultrasensitive and Highly Selective Electrochemical Biosensor for HIV Gene Detection Based on Amino-Reduced Graphene Oxide and $\beta$-cyclodextrin Modified Glassy Carbon Electrode
}

\author{
Jiawen Li, Xiaoyu Jin, Mengmeng Feng, Shan Huang ${ }^{*}$, Jinrong Feng ${ }^{*}$ \\ College of Chemistry and Materials Science, Guangxi Key Laboratory of Natural Polymer Chemistry \\ and Physics, Nanning Normal University, Nanning 530001, P. R. China \\ *E-mail: huangs@,whu.edu.cn, 1278281915@qq.com
}

doi: $10.20964 / 2020.03 .62$

Received: 8 November 2019 / Accepted: 27 December 2019 / Published: 10 February 2020

\begin{abstract}
A differential pulse voltammetry (DPV) platform for the sensing of human immunodeficiency virus (HIV) gene was described through the self-assembling of amino-reduced graphene oxide $\left(\mathrm{NH}_{2}-\mathrm{rGO}\right)$ and $\beta$-cyclodextrin $(\beta-C D)$ on the surface of glassy carbon electrode (GCE). It is making use of the single-stranded DNA (ssDNA) with sequence hybridized with HIV gene. The ssDNA was attached on $\mathrm{NH}_{2}-\mathrm{rGO} / \beta-\mathrm{CD}$ modified GCE $\left(\mathrm{NH}_{2}-\mathrm{rGO} / \beta-\mathrm{CD} / \mathrm{GCE}\right)$ surface, then methylene blue (MB) was interacted with ssDNA to general obvious DPV signal. The HIV gene was then initiated to hybridize with ssDNA on $\mathrm{NH}_{2}-\mathrm{rGO} / \beta-\mathrm{CD} / \mathrm{GCE}$ surface, causing a dramatic decrease in DPV response of MB at potential of $-0.25 \mathrm{~V}$ (vs. $\mathrm{Ag} / \mathrm{AgCl}$ ). Under optimal experimental conditions, response was linear in the $0.05 \mathrm{pM}$ to $1 \mathrm{pM}$ HIV gene concentration range. The electrochemical biosensor displayed an ultrahigh sensitivity with detection limit of $8.7 \mathrm{fM}$ and excellent selectivity. The modified electrode displayed good reproducibility, ultra-high sensitivity, and terrific selectivity. This electrochemical biosensor was successfully used for the determination of HIV gene in human serum samples.
\end{abstract}

Keywords: HIV gene; Differential pulse voltammetry; Amino-reduced graphene oxide; Biosensor; $\beta$ Cyclodextrin

\section{FULL TEXT}

(C) 2020 The Authors. Published by ESG (www.electrochemsci.org). This article is an open access article distributed under the terms and conditions of the Creative Commons Attribution license (http://creativecommons.org/licenses/by/4.0/). 